\title{
Prediction of Effective Elasticity Coefficients of Composite Biofuel
}

\author{
Vasyl Klymenko*, Volodymyr Kravchenko, Vasyl Gutsul, Viktoriya Kravchenko, Viacheslav Bratishko
}

\begin{abstract}
It is suggested that fuel pellets made of composites based on solid plant waste should be considered as stochastic systems that are anisotropic in microvolumes but isotropic in the entire structure, i.e. quasi-isotropic in volume. Based on this hypothesis and the analysis of the known micromechanical models for forecasting physical and mechanical constants of composite materials, the expediency of using the Reuss-Voigt and Hashin-Strickman models to determine the effective elastic coefficients of composite biofuels is substantiated. The results of calculations made on these models for a number of two-component biofuel pellets are given. An experimental evaluation of effective Young's modulus and Poisson's ratio for two-component pellets with "straw + brown coal" composition was carried out. The obtained results of experimentally determined values of coefficients satisfactorily correspond to their calculated values: deviations are up to $26 \%$. The Reuss-Voigt model was used in the calculations because the conditions required for the application of the Hashin-Strickman model are not met for composite pellets consisting of straw and brown coal. The results of the study will be useful in calculating or selecting press equipment for the production of quality fuel pellets from composites based on solid plant waste.
\end{abstract}

Keywords: biofuel; composite pellets; effective elastic constants; plant waste; Poisson's ratio; Young's modulus

\section{INTRODUCTION}

Plant agricultural waste, different types of wooden biomass and specially grown energy crops are significant biomass potential available for energy production [1].

To convert biomass into a form that is suitable for transportation and efficient energy use, a compaction process, known as pelletizing, is used.

The main advantages of using biofuel pellets are the following [1]:

- reduction of the harmful emissions into atmosphere: such fuel is $\mathrm{CO}_{2}$-neutral, i.e. the amount of the carbon dioxide which emitted into the atmosphere during its combustion does not exceed the amount of emissions that would have been generated by natural decomposition of biomass;

- higher calorific value, which exceeding the value of bulk biomass and approaching the calorific value of coal;

- low cost compared to fossil fuel resources.

Improvement of the usage efficiency for different types of solid plant waste can be achieved through the production of pellets made from composite materials, including other carbon-containing materials (e.g. household waste polyethylene terephthalate (PET), local fuels) $[1,2]$.

Exploitation of these fuels in power plants should achieve a synergistic effect as a result of more efficient use of biomass resources and a partial reduction of the negative impact on the environment as a result of waste disposal.

In a process of designing of the technological equipment for the production of solid composite biofuel and its subsequent transportation and use, it is necessary to consider the physical and mechanical characteristics of biofuel made of composite materials, in particular the elasticity constants [1]. Since composite fuels can include different components in different proportions with different individual elastic constants, the question of determining their elastic constants as solids with corresponding new properties in relation to its individual components is important and relevant.

Analysis of recent research and the publications. The pellets quality and their production energy consumption depend on the design parameters of the press equipment, the pressure on the raw material, as well as its physical and mechanical characteristics [1,3]. The required pressing pressure depends on both the technological and design characteristics of the press equipment and the elastic physical and mechanical properties of the raw material, namely the Young's modulus $E$ and Poisson's ratio $v[1,3]$.

Values of elastic properties of such materials as coal, wood, polymers and others are widely presented in the literature [3-5]. As for the study's results to determine the elastic properties of solid plant wastes, such information is presented much narrower. Some data about the elastic coefficients of composites, including plant wastes, which are mainly construction materials and products made using wood chips, are given in [6]. Article [7] considered issues of analytical determination of elastic constants of composite materials of multilayer shells with reinforcing material on the basis of epoxy matrix EM-20, but the obtained results of research cannot be directly used to calculate the effective elasticity constants (EEC) of composite biofuel.

The aim of the paper is to substantiate the choice of methodology for predicting the EEC of composite biofuel based on plant wastes (Poisson's ratio and Young's modulus) and experimentally assess the possibility of its practical application.

The choice of structural model of composite biofuel. Composite materials (CM) or composites consist of two or more components: discrete elements, which are reinforcement or reinforcement components, and a matrix that binds them together. $\mathrm{CM}$ have specific characteristics that differ from the total properties of the elements that make them up [6-14].

By the type of reinforcing components, which include various fibers, powders, spheres, crystals and other particles of organic and inorganic materials, CM is distinguished [12]: - multi-layered;

- fibrous, in which components of reinforcement are fibrous structures that can be oriented in different directions; 
- filled with CM, in which the components of reinforcement are heterogeneous particles.

According to the nature of distribution of reinforcement components, CM can be divided into periodic systems, stochastic mixtures and structured compositions.

Depending on the geometry of the reinforcement components and their relative position, $\mathrm{CM}$ can be isotropic, whose characteristics are the same in all directions, and anisotropic, whose characteristics differ depending on the orientation. Quasi-isotropic ones include stochastically reinforced $\mathrm{CM}$, whose reinforcing elements are short particles oriented randomly.

Composite fuel based on solid plant waste with an admixture of local fuels or household waste can be classified as stochastic systems whose components are chaotically distributed and do not form regular structures. At the same time, such a material is anisotropic in micro objects, but isotropic in the volume of the whole structure, that is, quasiisotropic.

In composite biofuel (CMB) based on plant waste in the form of pellets or briquettes, the structure-forming component (matrix) can be considered plant or wood waste with a lignin extracted during compression, which holds reinforcement components in the form of fillers (coal, household waste, etc.). In addition to increasing the density and heat of combustion of such CMB, it can be expected of its higher resistance to abrasion and destruction, which is important for the conditions of transportation, storage and movement in the elements of the power plant.

\section{SUBSTANTIATION OF THE METHOD FOR PREDICTING EFFECTIVE CONSTANTS OF ELASTICITY OF COMPOSITE BIOFUELS}

There are two alternative approaches to determine the elastic characteristics of composite material.

In the experimental approach, a certain structural element of the composite is investigated, the one which contains a sufficiently large number of reinforcing particles so that the results obtained for it could be generalized to any volume of composite material.

Application of this approach allows taking into account the change of elastic properties of the matrix and reinforcing fibers in the process of composite manufacturing. But in order to obtain a composite with the necessary properties it is necessary to conduct a large number of experiments, changing such parameters as the volume content of reinforcement, the nature of the location of reinforcing elements, the use of different materials for the matrix and reinforcing fibers. Therefore, such studies are carried out to refine theoretical models, or when the development or calculation of the latter is too complicated.

An alternative structural approach is the determination of the EEC of the composite through the elastic characteristics of the matrix and reinforcing material, their volume fractions in the composite, the dimensions and relative arrangement of reinforcing elements. A significant disadvantage of such an approach is that the elastic properties of structural components may differ significantly in the initial state and in the composition.

Also determining the value of the effective elastic coefficients of composite materials can be relevant by solving inverse problems of mathematical physics [15], as specific tasks where the desired variables are factors relevant model equations and the area where these equations are defined.

The most researched in the theory of composites and widespread in practice composite materials are materials with fibrous structure [16], to which CMB can be referred.

To determine the effective elastic characteristics in the mechanics of such CM there are various micro-mechanical methods of predicting the elasticity constants of fiber composites, based on a number of hypotheses and assumptions and allow us to consider the material in the CM layer transversal-isotropic [17].

In [18], the determination of the effective characteristics of unidirectional fibrous CM by structural parameters of material components is considered on the basis of known micromechanical models for the prediction of physicomechanical constants. These include models: Hill, Kilchinsky, Hashin-Rosen, Vanin, Reuss-Voigt.

According to Hill's model, the composite consists of a fiber that is in a coaxial matrix cylinder [18-20]. In the model of Kilchinsky [15, 18, 21, 22], Hashin-Rosen [15, 18, 20, 22] $\mathrm{CM}$ is considered as a fiber in the form of a cylinder, which is placed in a cylindrical shell - a matrix, which in turn is in an unbounded medium with elastic parameters equal to the effective parameters of the composite. Model Vanin [21] is used to determine the effective mechanical characteristics of unidirectional composites.

Model Reuss-Voigt [20, 22, 23] is used for composite, the structure of which can be considered as a system of rigidly bound isotropic rods, evenly arranged in an isotropic matrix. This model is in good agreement with the model of the composite biofuel structure chosen above, which makes it possible to calculate the elastic constants of CMB.

According to this model, a certain composite is matched with a homogeneous medium, for which elastic characteristics must be determined. We believe that Young's modules $E_{1}, E_{2}$ and Poisson's ratios $v_{1}, v_{2}$ of the twocomponent composite biofuel granule are known. The ratio of components is characterized by volume concentration $\gamma_{1}=$ $V_{1} / V$, where $V_{1}$ - the volume of the first component, $V$ - the volume of the whole granule.

According to the Reuss-Voigt model, the shear modulus $\mu$ and compression modulus $K$ satisfy the following inequalities:

$\mu_{\mathrm{r}} \leq \mu \leq \mu_{\mathrm{v}}, K_{\mathrm{r}} \leq K \leq K_{\mathrm{v}}$

where $\mu_{\mathrm{r}}$ and $\mu_{\mathrm{v}}$ are the shear modules of Reuss and Voigt respectively; $K_{\mathrm{r}}$ and $K_{\mathrm{v}}$ are the compression modules of Reuss and Voigt respectively.

The Reuss and Voigt modules are defined through component modules using the following formulas: 


$$
\begin{aligned}
& \mu_{v}=\gamma_{1} \mu_{1}+\left(1-\gamma_{1}\right) \mu_{2}, \quad \mu_{r}=\frac{\mu_{1} \mu_{2}}{\left(1-\gamma_{1}\right) \mu_{1}+\gamma_{1} \mu_{2}}, \\
& K_{v}=\gamma_{1} K_{1}+\left(1-\gamma_{1}\right) K_{2}, \quad K_{r}=\frac{K_{1} K_{2}}{\left(1-\gamma_{1}\right) K_{1}+\gamma_{1} K_{2}} .
\end{aligned}
$$

The intervals of possible values of the effective modules, which are set by formulas (1) - (3), are often quite large.

In some cases, these intervals can be significantly reduced by using the variational principle of the HashinStrickman model $[24,25]$, which is developed for investigate inhomogeneous elastic materials based on the generalization of the Lagrangian variational principle. Together with the inhomogeneous body that is studied, some homogeneous elastic body (comparison body) is considered.

On the basis of the Lagrangian, a functional is constructed, which has a minimum in the equilibrium position if the tensor of the elasticity modules of the examined body is "smaller" than the tensor of the elasticity modules of the comparison body and has a maximum in the equilibrium position if the tensor of the elasticity modules is "larger" than the tensor of the elasticity modules of the comparison body. If $K_{1}>K_{2}$ and $\mu_{1}>\mu_{2}$, so, this approach gives the following relations for the shear modulus and compression modulus:

$$
\mu_{\mathrm{h}} \leq \mu \leq \mu_{\mathrm{s}}, K_{\mathrm{h}} \leq K \leq K_{\mathrm{s}}
$$

where $\mu_{\mathrm{h}}$ and $\mu_{\mathrm{s}}$ are the shear modulus of Hashin and Strickman, respectively; $K_{\mathrm{h}}$ and $K_{\mathrm{s}}$ are the compression modules of Hashin and Strickman, respectively, which are defined:

$$
K_{\mathrm{h}}=\frac{K_{1} K_{2}+\frac{4}{3}\left(1-\gamma_{1}\right) \mu_{2} K_{2}+\frac{4}{3} \gamma_{1} \mu_{2} K_{1}}{K_{1}+\frac{4}{3} \mu_{2}-\gamma_{1}\left(K_{1}-K_{2}\right)},
$$

$$
\begin{aligned}
& K_{\mathrm{s}}=\frac{K_{1}\left(K_{2}+\frac{4}{3} \gamma_{1} \mu_{1} K_{2}\right)+\frac{4}{3}\left(1-\gamma_{1}\right) \mu_{1} K_{2}}{K_{1}+\frac{4}{3} \mu_{1}-\gamma_{1}\left(K_{1}-K_{2}\right)}, \\
& \mu_{\mathrm{h}}=\frac{5 \gamma_{1}\left(\mu_{1}-\mu_{2}\right)\left(3 K_{2}+4 \mu_{2}\right) \mu_{2}}{5\left(3 K_{2}+4 \mu_{2}\right) \mu_{2}+6\left(\mu_{1}-\mu_{2}\right)\left(K_{2}+2 \mu_{2}\right)\left(1-\gamma_{1}\right)}, \\
& \mu_{\mathrm{s}}=\frac{5\left(1-\gamma_{1}\right)\left(\mu_{2}-\mu_{1}\right)\left(3 K_{1}+4 \mu_{1}\right) \mu_{1}}{5\left(3 K_{1}+4 \mu_{1}\right) \mu_{1}+6\left(\mu_{2}-\mu_{1}\right)\left(K_{1}+2 \mu_{1}\right) \gamma_{1}} .
\end{aligned}
$$

The shear modulus and compression modulus can be expressed through the Young's modulus and Poisson's ratio [24]:

$$
K=\frac{E}{3(1-2 v)}, \quad \mu=\frac{E}{2(1+v)} .
$$

The above approaches can be applied to specific composite materials based on solid plant waste. First, it can be determined $K_{1}, K_{2}, \mu_{1}, \mu_{2}$, and then to calculate $K_{\mathrm{v}}, K_{\mathrm{r}}, \mu_{\mathrm{v}}$, $\mu_{\mathrm{r}}, K_{\mathrm{h}}, K_{\mathrm{s}}, \mu_{\mathrm{h}}, \mu_{\mathrm{s}}$, using Eqs. (2), (3), (5) - (8). The technical characteristics of the composite material may be based on the arithmetic mean of the corresponding values, namely

$$
\begin{aligned}
& \mu_{\mathrm{rv}}=\frac{\mu_{\mathrm{r}}+\mu_{\mathrm{v}}}{2}, K_{\mathrm{rv}}=\frac{K_{\mathrm{r}}+K_{\mathrm{v}}}{2}, \\
& \mu_{\mathrm{hs}}=\frac{\mu_{\mathrm{h}}+\mu_{\mathrm{s}}}{2}, K_{\mathrm{hs}}=\frac{K_{\mathrm{h}}+K_{\mathrm{s}}}{2} .
\end{aligned}
$$

\begin{tabular}{|c|c|c|c|c|c|c|c|c|c|c|}
\hline component 1 & $v_{1}$ & $E_{1}$ & $K_{1}$ & $\mu_{1}$ & $K_{\mathrm{h}}$ & $\mu_{\mathrm{h}}$ & $K_{\mathrm{r}}$ & $\mu_{\mathrm{r}}$ & $v_{\mathrm{hs}}$ & $E_{\mathrm{hs}}$ \\
\hline component 2 & $v_{2}$ & $E_{2}$ & $K_{2}$ & $\mu_{2}$ & $K_{\mathrm{s}}$ & $\mu_{\mathrm{s}}$ & $K_{\mathrm{V}}$ & $\mu_{\mathrm{v}}$ & $v_{\mathrm{rv}}$ & $E_{\mathrm{rv}}$ \\
\hline straw & 0.124 & 3158 & 1400 & 1405 & - & - & 2196 & 1151 & - & - \\
\hline PET & 0.41 & 2750 & 5093 & 975.2 & - & - & 3246 & 1190 & 0.312 & 3071 \\
\hline straw & 0.124 & 3158 & 1400 & 1405 & 1280 & 1297 & 1274 & 1294 & 0.121 & 2909 \\
\hline pine tree & 0.118 & 2680 & 1169 & 1199 & 1280 & 1298 & 1285 & 1302 & 0.121 & 2909 \\
\hline husk of sunflower & 0.125 & 3441 & 1529 & 1529 & 1463 & 1466 & 1462 & 1464 & 0.125 & 3297 \\
\hline straw & 0.124 & 3158 & 1400 & 1465 & 1463 & 1466 & 1465 & 1467 & 0.125 & 3296 \\
\hline husk of sunflower & 0.125 & 3441 & 1529 & 1529 & 1338 & 1353 & 1325 & 1344 & 0.122 & 3037 \\
\hline pine tree & 0.118 & 2680 & 1169 & 1199 & 1340 & 1354 & 1349 & 1364 & 0.122 & 3037 \\
\hline oak tree & 0.127 & 2987 & 1335 & 1325 & 1250 & 1.26 & 1247 & 1259 & 0.123 & 2830 \\
\hline pine tree & 0.118 & 2680 & 1169 & 1199 & 1250 & 1.26 & 1252 & 1262 & 0.123 & 2829 \\
\hline
\end{tabular}

On the basis of Eq. (9), we obtain backward transition formulas:

$$
v=\frac{3 K-2 \mu}{2(3 K+\mu)}, \quad E=\frac{9 K \mu}{3 K+\mu} .
$$

Using the last Eq. (11), can be defined $E_{\mathrm{rv}}, v_{\mathrm{rv}}, E_{\mathrm{hs}}, v_{\mathrm{hs}}$.

Table 1 Results of calculations of elastic constants for composite pellets based on plant waste

The Reuss-Voigt model can be applied to any biofuel composite for it can determine the values of the effective elastic coefficients in a wide range, but it can lead to large errors in determining their values.

When calculating the Hashin-Strickman model, one can expect a smaller error in the determination of EEC composite biofuels. However, the range of use of this model is considerably narrower and it can be applied only if conditions $K_{1}>K_{2}$ and $\mu_{1}>\mu_{2}$ are met at the same time. If $v_{1}$ $=v_{2}$, then from Eq. (9) it follows that the indicated inequalities are guaranteed to be fulfilled at $E_{1}>E_{2}$. If, for example, $v_{1}$ increases with a constant value of $v_{2}$, then this 
leads to an increase in $K_{1}$ and a decrease in $\mu_{1}$, which in turn leads to a violation of the above conditions. Thus, Hashin'sStrickman's approaches can only be applied when the values of Poisson's ratios of the biofuel composite are close.

Tab. 1 shows the results of calculations of elastic constants of composite biofuel pellets according to the above mentioned models of Reuss-Voigt and Hashin- Shtrickman. Pellets composition was chosen on the basis of common plant wastes.

For calculations of the average values of the elastic constants of composite components were used, because their values given in the literature sources differ significantly for the same materials $[3,4,26,27]$. In all cases, the value of Young's modulus was set in MPa and taken as $\gamma_{1}=0.5$.

Analysis of the results given in Tab. 1 shows that the calculated values of EEC for composite pellets on the basis of common plant waste obtained from Reuss-Voigt and Hashin-Shtrickman models practically do not differ. Therefore, the application of the Reuss-Voigt model is sufficient for composite biofuels, since its use is possible for a wider range of elastic characteristics of $\mathrm{CMB}$ components.

\section{METHODOLOGY AND RESULTS OF EXPERIMENTAL STUDIES}

The testing machine UIP-50 which was used for experimental verification of the calculation method of elastic constants of composite pellets is universal, and the investigated sample of pellets was located in its working part shown in Fig. 1.

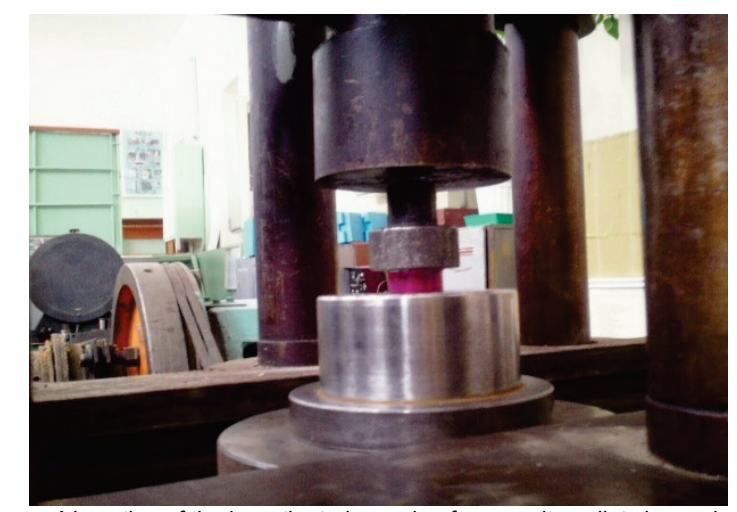

Figure 1 Location of the investigated sample of composite pellets in a universal testing machine

In order to correct possible traction irregularities and remove backlashes in the testing machine load system, a preload of $100 \pm 1 \mathrm{H}$ was carried out.

Deformation by compression of the specified sample was performed with simultaneous recording of the deformation diagram.

The specimen was compressed and fixed the amount of movement of the moving traverse. Values of the compression force were measured using a force meter, the, which were also displayed on the device for recording the graph of the relationship between the load and the movement of the traverse.
According to the recorded deformation diagrams, the Young's modulus of the sample was determined $E=$ $(P / F) /(\Delta l / l)$, where $\Delta l / l=\varepsilon-$ relative longitudinal deformation; $P$ - compression force applied to the sample; $F$ - cross-sectional area of the sample; $\Delta l$ - change in the longitudinal deformation of the sample; $l$-initial height of the sample.

To determine the Poisson's ratio, the geometric dimensions of the samples were measured before and after loading:

$v=\frac{\varepsilon^{\prime}}{\varepsilon}$

where $\varepsilon^{\prime}=\Delta d / d-$ is the relative lateral deformation; $\Delta d-$ is the amount of the change in lateral deformation of the sample; $d-$ is the initial diameter of the sample.

Values for determining the relative longitudinal and lateral deformations were measured at the beginning of crack formation on the specimens, which appeared on the peripheral parts of them before the subsequent destruction with the separation of individual material particles.

An electronic control caliper with a measurement value of $0.01 \mathrm{~mm}$ was used as a control instrument.

In experiments, samples of two-component pellets consisting of straw $\left(E=3160 \mathrm{MPa}, v_{2}=0.124\right.$ [3] $)$ and brown coal $\left(E=3020 \mathrm{MPa}, v_{1}=0,3\right.$ - dataset for coal [28]) were used for the corresponding $\gamma_{1}=0.1 ; 0.2 ; 0.3$ These samples were made on the above-mentioned universal testing machine using a special press device. The samples had the sizes $d=27 \mathrm{~mm}, l=20 \mathrm{~mm}$, and for their manufacture straw particles with fraction up to $4.0 \mathrm{~mm}$ and crushed brown coal with fraction up to $1.0 \mathrm{~mm}$ were used.

To evaluate the method of experimental determination of the elastic coefficients of a composite sample on the basis of plant wastes, an experimental determination $E$ and $v$ of a similar sample $(d=27 \mathrm{~mm}, l=20 \mathrm{~mm})$ made of pine was carried out using this method.

The obtained values of elastic coefficients of pine samples $(E=3.85 \mathrm{GPa}, v=0,4)$ are satisfactory with the corresponding values of $E=4.0 \mathrm{GPa}, v=0.45$, given in [29].

Results of experimental determination of elastic constants of composite granules samples are given in Tabs. 2 and 3 .

Table 2 Results of experimental determination of Young's modulus values of composite pellets

\begin{tabular}{|c|c|c|c|c|c|c|}
\hline \multirow{3}{*}{$\begin{array}{c}\text { Volume } \\
\text { concentration of } \\
\text { brown coal }\end{array}$} & \multicolumn{5}{|c|}{$E$} & \multirow{3}{*}{$\begin{array}{c}\Delta E, \\
\%\end{array}$} \\
\hline & \multicolumn{3}{|c|}{ No. Experiment } & \multirow{2}{*}{$E_{\mathrm{av}}$} & \multirow{2}{*}{$\begin{array}{l}\text { By the model } \\
\text { Reuss-Voigt }\end{array}$} & \\
\hline & 1 & 2 & 3 & & & \\
\hline$\gamma_{1}=0.1$ & 2630 & 2644 & 2678 & 2650.6 & 3161 & 16 \\
\hline$\gamma_{1}=0.2$ & 2809 & 2848 & 2858 & 2838.3 & 3158 & 10 \\
\hline$\gamma_{1}=0.3$ & 3101 & 3180 & 3194 & 3158.3 & 3150 & 0.3 \\
\hline
\end{tabular}

${ }^{*} \Delta E$ - deviation of the calculated values from the experimental ones

Tabs. 2 and 3 show the comparative results of experimental studies with the results of the Reuss-Voigt model calculations, since the conditions $K_{1}>K_{2}$ and $\mu_{1}>\mu_{2}$ are not fulfilled for the composite consisting of straw and 
brown coal, and in this case it does not allow using the Hashin-Strickman model for calculations.

Table 3 Results of experimental determination of Poisson's ratio values composite pellets

\begin{tabular}{|c|c|c|c|c|c|c|}
\hline \multirow{2}{*}{$\begin{array}{c}\text { Volume } \\
\text { concentration of } \\
\text { brown coal }\end{array}$} & \multicolumn{5}{|c|}{$v$} & \multirow{2}{*}{\begin{tabular}{c}
$\Delta v$, \\
\cline { 2 - 5 }
\end{tabular}} \\
\cline { 2 - 5 } & \multicolumn{2}{|c|}{ No. Experiment } & $\begin{array}{c}\text { By the model } \\
\text { Reuss-Voigt }\end{array}$ & \\
\hline$\gamma_{1}=0.1$ & 0.120 & 0.121 & 0.122 & 0.121 & 0.146 & 17 \\
\hline$\gamma_{1}=0.2$ & 0.123 & 0.123 & 0.124 & 0.1233 & 0.167 & 26 \\
\hline$\gamma_{1}=0.3$ & 0.144 & 0.146 & 0.147 & 0.1456 & 0.187 & 22 \\
\hline
\end{tabular}

$* \Delta v-$ deviation of the calculated values from the experimental ones

The analysis of the obtained results shows the satisfactory correspondence of the obtained calculated values of the effective elastic constants of the composite pellets to their experimentally determined values: deviations of Young's modulus value do not exceed $16 \%$ and Poisson's ratio $26 \%$.

In [3] on the basis of experimental studies it was shown that Young's modulus for a solid body formed from disperse biomaterials of plant origin, depending on the applied load at the deformation site remained unchanged (error within 5\% $15 \%$ ). By analogy, the elastic constants can be assumed to be constant for pellets formed from composite material based on dispersed solid plant waste.

The results obtained suggest a considered approach for predicting the effective elastic constants of composite biofuels required for the calculation or selection of press equipment for the production of quality fuel pellets from composites based on solid plant waste.

In the end it should be noted that the values of elastic constants given in the literature sources for the same plant materials may differ significantly $[3,26]$.

Therefore, the values of the predicted quantities of the EEC of the composite biofuels will significantly depend on the right choice in each case of the quantities of the corresponding coefficients of composite materials components.

\section{CONCLUSIONS}

It has been suggested to consider fuel pellets made of composites based on solid plant waste as stochastic quasisystems in which a structural component (matrix) can be considered as plant waste emitting lignin during compression.

The analysis of known micromechanical models for the prediction of physico-mechanical constant composite materials is carried out. To determine the effective elastic coefficients of composite biofuels, the feasibility of using the Reiss-Voigt and Hashin-Strickman models, the conditions of use of these models and the EPC of two-component pellets containing distributed plant waste were calculated.

Experimental estimation of the values of the effective Young's modulus and the Poisson's ratio for pellets of the "straw + brown coal" mixture was performed. Comparison of experimental and analytically determined values of the coefficients of elasticity showed that the deviations for the
Young's modulus are in the range up to $16 \%$ and for the Poisson's ratio in the range up to $26 \%$.

The results obtained allow recommending the considered approach to predict the effective elasticity constants of composite biofuel required in the calculation or selection of press equipment for the production of quality fuel pellets from composites based on solid plant waste.

\section{REFERENCES}

[1] Klymenko, V. V., Kravchenko, V. I., Bokov, V. M., \& Gutsul, V. I. (2017). Tehnologichni osnovy vygotovlennja biopalyva z roslynnyh vidhodiv ta jih kompozytiv: Monografija. PP Ekskljuzyv-System.

[2] Klymenko, V. V., Kravchenko, V. I., Kyrychenko, A. M, Lychuk, M. V., \& Soldatenko, V. P. (2016). Eksperymental'na ocinka vygotovlennja tverdogo biopalyva $\mathrm{z}$ kompozytiv na osnovi roslynnyh vidhodiv. Energotehnologyy $y$ resursosberezhenye. 3, 18-24. http://nbuv.gov.ua/UJRN/ ETRS 201634

[3] Shtefan, Je., Ryndjuk, D., \& Taran, O. (2012). Doslidzhennja strukturno-mehanichnyh vlastyvostej dyspersnyh materialiv roslynnogo pohodzhennja. Zbirnyk naukovyh prac' Vinnyc'kogo nacional'nogo agrarnogo universytetu. Serija: Tehnichni nauky. 10 T. 1 (58), 181-185. http://nbuv.gov.ua/UJRN/znpvnutn 2012 10(1) 36.

[4] See http://www.eplastic.ru/spravochnik/materiali/pet.

[5] See http://www.stroymehanika.ru/obsh_sved.php.

[6] Chudanova, Je. L. \& Hazipova, V. V. (2013). Zmenshennja vidhodiv u naprjamku oderzhannja derevoplastu. Visnyk Donbas'koji nacional'noji akademiji budivnyctva i arhitektury, 5(103), 105-109. http://nbuv.gov.ua/UJRN/vdnaba 2013 5_21.

[7] Bazhenov, V. A. \& Kryvenko, O. P. (2017). Zastosuvannja metodyk prognozuvannja pruzhnyh harakterystyk kompozytnogo materialu v skinchennoelementnij modeli obolonky neodnoridno ji struktury. Opir materialiv $i$ teorija sporud. Kyiv. KNUBA, 98, 3-15. http://opir.knuba.edu.ua/ zbirnyk-98/article-802

[8] Dobrydenko, O. M., Skljar, O. I., Turchyn, V. M. \& Bjelins'ka, R. B. (2012). Analiz isnujuchyh kompozytnyh materialiv ta ocinka jih zastosuvannja u konstrukcijah planeriv lital'nyh aparativ vijs'kovoji aviaciji Ukrajiny. Zb. nauk. prac' Derzhavnogo naukovo-doslidnogo instytutu aviaciji, 15, 147152. http://nbuv.gov.ua/UJRN/Znpdndia_2012_8(15)_24.

[9] Kos, Z., Vyrovoi, V., Sukhanov, V., Zavoloka, M., Gokhman, A., \& Grynyova, I. (2019). Optimization of the structure of insulating composite materials. Technical Journal, 13(1), 5762. https://doi.org/10.31803/tg-20181206205307

[10] Shevchenko, V. (2010). Osnovy fyzyky polymernyh kompozycyonnyh materyalov. Moskva. MGU.

[11] Vyshnjakov, L. \& Grudyna, T. (1985). Kompozycyonnye materyaly. Kyev, Naukova dumka.

[12] Torquato, S. (2002). Random Heterogeneous Materials. Microstructure and Macroscopic Properties. New York, Springer. https://doi.org/10.1007/978-1-4757-6355-3

[13] Mett'juz, F. \& Rolyngs, R. (2004). Kompozytnye materyaly. Mehanyka y tehnologyja. Moskva. Tehnosfera.

[14] Kovalenko, V. \& Kondrat'yev, A. (2011). Primeneniye polimernykh kompozitsionnykh materialov $\mathrm{v}$ izdeliyakh raketno-kosmicheskoy tekhniki kak rezerv povysheniya yeye massovoy i funktsional'noy effektivnosti. Aviatsionnokosmicheskaya tekhnika $i$ tekhnologiya, 5, 14-20. http://nbuv.gov.ua/UJRN/aktit_20115 5 
[15] Kucher, M. K. (2010) Ocinka mikromehanichnyh modelej prognozuvannja efektyvnyh konstant pruzhnosti voloknystyh kompozytiv. Visnyk Nacional'nogo tehnichnogo universytetu Ukrajiny "Kyjivs'kyj politehnichnyj instytut". Serija Mashynobuduvannja, 58, 24-29. https://ela.kpi.ua/bitstream/ 123456789/4482/1/24.pdf

[16] Lobur, M., Farmaga, I., Marikutsa, U., Matviykiv, O., \& Ciupinski, L. (2011). Analysis and Problem Statement of the Optimal Thermal Design of Technical Objects. Proc. of the Inter. Conf. MICROTHERM. Lodz, Poland, June 28 - July 1, 223-227.

[17] Jaworski, N., Farmaga, I., Lobur, M., \& Spievek, P. (2013). Research of composite materials optimal design task based on numerical simulation. Proc. of the $8^{\text {th }}$ Int. Scientific and Technical Conference "Computer Sciences and Information Technologies (CSIT'2013)". Lviv. 46-48. https://www.researchgate.net/publication/272826895_Researc h_of_composite_materials_optimal_design_task_based_on_n umerical_simulation

[18] Solovej, M. O., Kryvenko, O. P., \& Mischenko, O. O. (2013). Vyznachennja efektyvnyh fizykomehanichnyh harakterystyk odnosprjamovanogo voloknystogo kompozytnogo material. Opir materialiv $i$ teorija sporud. Kyiv, KNUBA, 92, 30-49. http://opir.knuba.edu.ua/zbirnyk-92/article-545

[19] Gajdachuk, A. V., Chesnokov, A. V., Gurin, I. V., \& Potapov, A. M. (2013). Predposylky dlja polnogo cykla proyzvodstva uglerod uglerodnyh kompozycyonnyh materyalov v Ukrayne. Avyacyonno-kosmycheskaja tehnyka y tehnologyja, 2 (99). 413. http://nti.khai.edu:57772/csp/nauchportal/Arhiv/AKTT/ 2013/AKTT213/Gaydach.pdf

[20] Brautmana, L. \& Kroka, R. (1978). Kompozycyonnye materyaly. T. 2. Mehanyka kompozycyonnyh materyalov. Moskva, Myr.

[21] Vanyn, G. A. (1971). Mykromehanyka kompozycyonnyh materyalov. Kyiv, Naukova dumka.

[22] Karpynos, D. M. (1985). Kompozycyonnye materyaly: Spravochnyk. Kyiv, Naukova dumka.

[23] Pobedrja, B. E. (1984). Mehanyka kompozycyonnyh materyalov. Moskva, Yzd-vo Mosk. un-ta.

[24] Fylyn, A. P. (1975). Prykladnaja mehanyka tverdogo deformyruemogo tela. T1. Moskva, Nauka.

[25] Hashin, Z. \& Shtrikman, S. (1962). On some variational principles in anisotropic and nonhomogeneous elasticity. Journal of the Mechanics and Physics of Solids, 10(4), 335342. https://ui.adsabs.harvard.edu/abs/1962JMPSo..10..335H/ abstract. https://doi.org/10.1016/0022-5096(62)90004-2

[26] Vorob'ev, G. Y. (1986). Lesnaja encyklopedyja. Moskva. Sov. encyklopedyja.

[27] See http://www.stroymehanika.ru/obsh_sved.php

[28] Stepanov, Ju. S. \& Andruschenko, V. A. (1990). O mehanyzme samovozgoranyja uglja. Fizika goreniya $i$ vzryva, 2, 23-28. http://www.sibran.ru/upload/iblock/636/63688359df7a85925b 56267def79e413.pdf

[29] See https://mash-xxl.info/tabs/115148/.

\section{Authors' contacts:}

Vasyl Klymenko, Doctor of Technical Sciences, Professor of the Department of Electrotechnical Systems and Energy Management, Central Ukrainian National Technical University

Universytetskyi Ave, 8, Kropyvnytskyi, Ukraine, 25006

E-mail: klymvas@ukr.net

Contact tel.: +380 974862754

ORCID: http: //orcid.org/0000-0001-6840-7307
Volodymyr Kravchenko, Candidate of Technical Sciences, Associate Professor of the Department of Electrotechnical Systems and Energy Management, Central Ukrainian National Technical University

Universytetskyi Ave, 8, Kropyvnytskyi, Ukraine, 25006

E-mail: cerb_kravchenko@ukr.net

Contact tel.: + 380667231077

ORCID: http://orcid.org/0000-0002-4989-1591

Vasyl Gutsul, Candidate of Technical Sciences, Associate Professor of the Department of Higher Mathematics and Physics

Central Ukrainian National Technical University

Universytetskyi Ave, 8, Kropynnytskyi, Ukraine, 25006

E-mail: vigutsul@ukr.net

Contact tel.: +380 962285336

ORCID: http://orcid.org/0000-0003-4155-5355

Viktoriya Kravchenko, Candidate of Economic Sciences, Associate Professor of the Department of Finance, Banking and Insurance,

Central Ukrainian National Technical University

Universytetskyi Ave, 8, Kropynnytskyi, Ukraine, 25006

E-mail: kravchen64@ukr.net

Contact tel.: +380 507624775

ORCID: http://orcid.org/0000-0003-4343-6296

Viacheslav Bratishko, Doctor of Technical Sciences, Head of the Department of Transport Technologies and Means in Agroindustrial Complex,

National University of Life and Environmental Sciences of Ukraine

Heroiv Oborony Str., 15, Kyiv, Ukraine, 03041

E-mail: vbratishko@nubip.edu.ua

Contact tel.: +380 982079277

ORCID: https://orcid.org/0000-0001-8003-5016 